\title{
Inferiority complex or competitive success: An analysis on the national identity of Turkish product design practice
}

abstract The paper discusses the evaluation of globalization and the national identity in terms of its effects on design discourse. With the established theoretical framework, the special focus is put on the analysis of the national identity of Turkish design that is mostly based on traditional values. In the study, literature review and discourse analysis are applied as methods of inquiry in exploring how designers represent culture and construct a Turkish design identity in their works. Based on the analysis, the following discussion is raised; if cultural representation of design is a need of competitive success in a globalized market or a result of an inferiority complex inherited from anachronism for many years.

keywords globalization, national identity, turkish design, cultural representation

\section{Introduction}

\section{Globalization and Reflection of National Identity}

"Identity is often said to be a relation each thing bears to itself and to no other thing." (Deutsch, 2008). Identity is the quality of individuality and gains meaning when 'other' is defined. Identity is uniqueness; but also has a comparative existence. As a matter of fact, the need for belonging to a collective identity with the motive to keep the uniqueness is self-contradictory.

This situation can be generalized for nations and 'national identity' in turn in today's globalized world. As indicated by Aldersley-Williams (1992, p. 426), since Second World War, globalization has transformed our lives in many ways that appear to reduce the importance of national borders. In this brand new globalized world, with the help of the technological advancements, people can communicate and move from somewhere to another easily; also with the changing dynamics of the economy, trade between nations has been growing rapidly and politically all the nations are interconnected to each other closely. When it comes to its effect on cultures and national identities, these issues are getting far more intriguing. According to Kongar (1997), globalization has two very different, even contrary effects on culture; one is uniformity and mono-culturalization, which is related to consumerism and controlling people's consumption habits in global scale. The other is micro-nationalism, meaning emphasizing even the tiniest cultural differences and preserving the cultural differences as a basic democratic right and freedom of individuals. This two contrasting effects of globalism on culture might be compared to the 'identity' claim, mentioned as self-contradictory above. 
Design, generally and mistakenly accepted as a sole economic activity, is actually both creator and conveyor of cultures; since products shapes cultures and lifestyles and the reverse is also true. In this context, target group would not only be consumers but also culture perpetuators. Therefore designers, in this context are seen as responsible for 'designing cultures' as well (Bayrakçı 1996, p. 95). However, the uniformity proposal, as mentioned above, reflects itself as 'universal or global design' in industrial design field. These works without any cultural identity, which targets the 'Western' urbanized consumers, ignored the variety of cultures and reduce its users to an artificial one (p. 94).

Under these circumstances, designers have a paradox that "they do not wish to abet the emergence of narrow political nationalism through their design that celebrates national cultures, but neither have they seen much inspire them in the only apparent alternative of global design." (Aldersley-Williams 1992: 426). As similarly Ricoeur (quoted in AldersleyWilliams 1992: 427) sees universalization as "an advancement of mankind, at the same time constitutes a subtle destruction, not only of traditional cultures ... but also ... the creative nucleus of great cultures." All these concerns led to a global inclination to protect or create a national style - a national design identity, as a concern of designers. This view is inevitably rooted in the dynamics of global economy as many authors indicated. For example, Porter (1990) identifies cultural differences as a key factor for competitive success. Supporting Porter's ideas further, Loek van der Sandre, a former president of ICSID, remarks that "culture is the world commodity of the 21st century." believing that in the future national identities will become a tradable item (quoted in Aldersley-Williams 1992: 431). Supporting all these claims, Er (2007) suggests that constant innovation demands of global capital brought about the inclining use of cultural resources for differentiation and novelty.

All these discussions raise the following questions: how could designers affirm any cultural identity? And what is identity in product design? Harel and Prabhu defined the cultural characteristics as "cultural values that individuals in a society may share regardless of their unique perspectives" (1989: 206). Aynsley (1993) in his book argues that diverse applications of materials and techniques affect the way a product looks and consequently this can be observed how a nation reflects its design identity. Kelley's contribution in here is that national identity is sustained more in products with a relatively long history such as furniture, hand tools and kitchen utensils (2001). National design identity can be exemplified with some distinguishing characteristics. Kaygan (2006, p. 27) identifies some attempts to define the qualitative characteristics of designs of Japanese as 'austere and traditional', German as 'rationalist' and Italian as 'playful'.

\section{Turkish Design Discourse}

When considering Turkey in this context, the reflection of Turkish cultural identity into the products is still controversial and looks like to be nourished from many different visual sources. Er (2009) describes this issue as 'integration of local cultural values into a modern design identity' and explains that after the 2001 Turkish economic crisis, Turkish companies were motivated to innovate as a result of global competitive pressures, and designers started to use cultural elements as a resource of inspiration, as an answer. Consequently, Turkish design abandoned its prolonged modernist design language which ignored any local cultural references.

This case can be explained with the Appadurai's proposition that "in the peculiar chronicities of capitalism, pastiche and nostalgia are central modes of image 
production and reception... [The past] has become a synchronic warehouse of cultural scenarios."(1996: 30).

Supporting this idea, Kaygan identifies some ethno-cultural sources like Anatolian civilizations, Central Asia Turks, Anatolian local cultures and Ottoman Empire with the emphasis on the concepts related to Ottoman together with the city of Istanbul; he adds that the visual elements originated from Turkish/Eastern/traditional figures are got together with Western materials and production techniques (2008, p.124). Turkish designers have different approaches when adopting these resources. Karakus in his book, Turkish touch in design, categorizes these different approaches of different designers. Based on the free-lance designers exhibiting their works in the exhibition 'ilk(means 'first' in Turkish) in Milano'- the first international scene that Turkish designers show their works in a coherent motto: 'Turkish touch in design'- he categorizes the participant designers in two groups as 'Turkish designers' and 'global Turks.'; explaining the former as consultant designers working in Turkey and for Turkish firms most of the time and the latter as the ones who have their career outside of the country despite the ongoing relations with Turkey. He declares that 'Turkish designers', as a common design approach, use a unique type of geometrical abstraction originated from not only Western rationalism but also nomadic culture. This type of geometric expression is comprised of the unification of Turkish western based design training and their intuitive approach to form giving affected by local influences. A small group of 'Turkish designers', however, tend to use direct reference to local sources different from the mentioned geometrical abstraction (Fig. 1 Left). The design language of 'Global Turks' (Fig. 1 - Right) on the other hand, thanks to their direct relation with western rationalism throughout their education and/or careers, is a more refined version of geometric abstraction. In their works, use of lighter and linear geometries, close to the pure raw state of the matter is observed, compared to the heavier or -as he names- 'clunky' geometries of Turkish designers (2007, pp. 22-27).
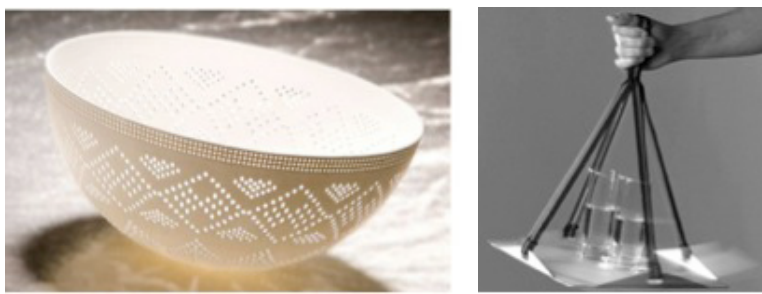

Balcioglu (1999) also makes a categorization of approaches of Turkish designers' listed as: neological, morphological, topographic, formal, allegorical, and conceptual approaches. Neological approach refers to a cultural attribution through names; morphological is through shapes, topological is through shapes that gained a three dimension and functionality, formal is through some changes in shape, while allegorical is through giving an old object a new function and finally conceptual is through a new interpretation of cultural norms, beliefs, social behaviors and acts.

Besides all these categorizations and efforts to understand whether a unique and single 'Turkish-ness' in design scene is possible or not, there are concerns for the intention, sincerity and success of this matter. For instance, Aydınlı raises her concerns that in countries with rich cultural heritage, transformation that rapid industrialization triggers eliminates the quality of production regarding design. Turkey, as in many matters also in design, aimed to reach the 'ideals' of western civilizations in revolutionary rather than evolutionary ways. Therefore, industrial design in Turkey has the danger not to internalize transformations because of its hesitation of cultural self positioning as West or East. She

Figure 1. Left - 'Hadji Collection' a decorative bowl inspired by Taqiyah, designed by Erdem Akan.

Right - 'Tipsy Tray' a traditional tea serving tray, designed by Koray Özgen 
opposes the use of historical or ethnic origins as a reference for design practice in monodimensional way, and supports the idea that good design (also art), as an end product of a multi-layered culture, is originated from the conflict and tension between the universal and local, individual and society (1999, pp. 115-117).

The concerns about the 'banal nationalism' and Orientalist point of view in the works of designers are also valid. For local values (originated from the East) to be accepted universally (mostly by the West), designers feel the need to rationalize these Eastern, so-called irrational feminine forms into a more refined and competent forms of Western (Kaygan, 2008, p. 124). From another point of view, Billig (1995) asserts that some ingrained forms of nationalism dominate in our everyday lives, as with the name he calls it 'banal nationalism'. This type of nationalism is beyond the level of conscious awareness and supported through routine symbols and habits of language via the help of many different media. Design is also a tool of reproduction of this type of nationalism and designer, as Kaygan (p. 128) indicates, has a passive role other than a productive one regarding the representation of a national culture. Turkish case can be seen an example to this mentality.

Constructing a national identity through traditional values with an indirect dictate of modernity discourse is also insincere. Indeed trying to find a cultural identity already contradicts with itself. This is especially valid when products are presented as an interpretation of local cultures in appeal of modernity, via for example geometrical abstraction. It is a fallacious attitude to show our modernity process as a natural one; because it was not, and it might be a reflection of an inferiority complex as a nation. At this point we may refer to Said's ideas of Orientalism as "a way of coming to terms with the Orient that is based on the Orient's special place in European Western experience." Defined as a place of "deepest and most recurring images of Other" (Said 1985: 1) east side of the world comes to exist with the West side's reference. The view of contrasting the geography and cultures of East with West and reduce Eastern culture as a one condensed image is the dominating idea of Orientalism (Orlandi, 2006, pp. 302-303). At this point, Turkish design should not be trapped in Western way of perceiving the world and be aware of the fact that with a self-Orientalist point of view, design outcomes cannot go further than some beautiful touristic objects, let alone bring a competitive success.

This self-Orientalist approach can be observed in how 'ilk in Milano' exhibition (previously mentioned) was reflected in press. Most of the products exhibited in this event were designs of local connotations and the meaning attributed to this exhibition was beyond showing products designed by Turkish designers; rather it was a strategic move to "show the harmonious synergies of the richness of Anatolian heritage transformed into contemporary design through the leading-edge technologies and manufacturing processes."(Karakusș2007: 136). In local publications the exhibition was reflected in some headlines as "Victory cry from Milano expedition", "Milano invasion from Turkish designers" and "ilk in Milano was a start", mentioned like a conquest or a military expedition of Turkish design.

The issue is that designers are not yet sure where to position Turkish design in this context; whether to modernity or traditional values. Capturing the contemporary spirit in designs is another concern. Maybe this ambiguity itself is the key for Turkish design to find itself. As Can Yalman, a prominent 'global' designer indicates in 2007 in an interview with Kapucu that 'inbetweenness' is an incredible source for a designer. Such being the case, this situation may be used for advantage. 


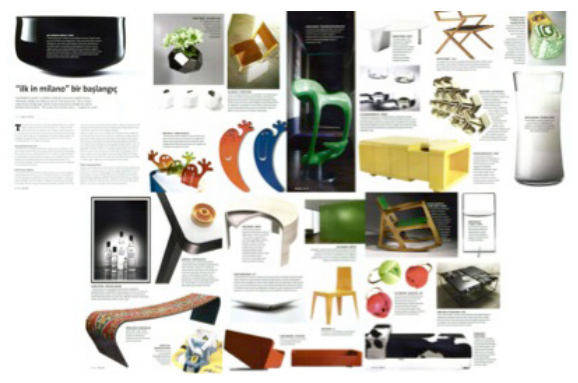

Figure 2. Photograph of designs in 'ilk in Milano'

\section{Instead of Conclusion}

With the established framework, it might be argued that Turkey is a scene of contradictions where a different mix of Eastern cultures dominated and was disrupted with rapid modernization movements with new Turkish republic, and now with dynamics of globalization, instead of an evolving mode of modernity in every aspect of life. In designers' works claiming to reflect 'cultural values' it can be observed that Turkish national identity is mostly based on traditional visual clues with weak contextual relationship and deprivation of meanings and essence, rather than focusing on the quality of design such as 'austere', 'rationalist' or 'playful'. Turkish interpretation of culture so far shows the superficiality of the matter. Culture is inseparable with its rituals and environments, a meaningful cultural reflection will be possible with reflecting it via products within their own context, instead of a single product in an irrelevant scene.

However, it should be kept in mind that it is still an ongoing search; and since industrial design is a young profession in Turkey, there is not enough evidence of industrial design activity yet to fully evaluate the cultural representations of design and draw valid conclusions about a solid Turkish national identity.

\section{References}

Aldersley-Williams, H. (1992) 'Globalism, Nationalism and Design', In H. Clarck and D. Brody (Eds.),Design studies: A reader (pp. 426-432) Oxford, England: MPG Books Group.

Appadurai, A. (1996) Modernity at large. Minneapolis, MN: University of Minnesota Press. Aydınlı, S. (1996) 'Ürün tasarımında kitsch kavramı üzerine' [On kitsch in product design], Proceedings of the and National Design Congress "Tasarımda Evrenselleșme". iTü Publications, i̇stanbul.

Aynsley, J. (1993) Nationalism and Internationalism: Design in the Twentieth Century, Victoria and Albert Museum, London.

Balcioglu, T. (1999) 'Problematic of local and global design identity in new industrialized countries with special emphasis on Turkey: Where does the hope lie? Exploited Promises of Globalization and Local Heroes', Proceedings of the Third European Academy of Design Conference vol. 1, Sheffield Hallam University, 3oth March - 1st April, Sheffield.

Bayrakçı, O. (1996) 'Yerel ürün kimligi-küresel dıs pazar'. [Local product identityglobal foreign market], Proceedings of the 2nd National Design Congress "Tasarımda Evrenselleșme". iTü Publications, İstanbul.

Billig M. (1995) Banal nationalism. London, Sage Publications.

Coskun Orlandi, A. (2006) 'Günümüzde Türkiye'de turistik metalar üzerindeki oryantalist etkiler ve bu çerçevede tasarımda ulusal kimlik'. [Orientalist effects on contemporary touristic objects in Turkey and national identity in design through this perspective], 
Proceedings of the 3rd National Design Congress "Türkiye 'de Tasarımı Tartışmak". ITÜ Publications, istanbul.

Deutsch, H. "Relative Identity", The Stanford Encyclopedia of Philosophy (Winter 2008 Edition), Edward N. Zalta (ed.), Available: http://plato.stanford.edu/archives/win2008/ entries/identity-relative/ [5 Apr 2014].

Er, H. A. (2007) Turkish touch in design: Geometrik soyutlama ve göçebe duyarliligi. [Turkish touch in design: Geometric abstraction and nomad sensibility]. Icon, 6,pp. 106-109.

Er, H. A. (2009) A creative convergence of modernity, globalization and tradition: understanding industrial design in Turkey. Asia Design Journal, vol.4 no. 4. 'Hadji Collection'. [Photopraph of 'Hadji Collection' a decorative bowl design by Erdem Akan], Available: http://www.erdemakan.com/?portfolio=Hadji_ Collection\&thumbposition=112 [15 Feb 2014]. Harel, D.and Prabhu,G. (1999) 'Global User Experience (GLUE). Design for cultural diversity: Japan, China and India, designing for global market'. Proceedings of the first international workshop on internationalization of products and systems, pp. 205-216. Karakartal, M. (2007) 'Milano seferinden zafer çı̆̆lığı geliyor'. [Victory cry from Milano expedition]. Radikal Cumartesi, Available: http://www.nurus.com/files/images/press/ zafer.jpg [26 Apr 2013].

Karakus, G. (2007) Turkish touch in design: contemporary product design by Turkish designers worldwide. İstanbul, Tasarım Yayın Grubu.

Kapucu, B. (2007) 'Interview with Can Yalman'. Icon, 3, 80-85.

Kaygan, H. (2006) 'Evaluation of products through the concept of national design; a case study on ArtDecor magazine'. Unpublished master's thesis, Middle East Technical University, Department of Industrial Design.

Kaygan, H. (2008) 'Tasarımda milli kimligin varolus kosulları'. [Existence conditions of national identity in design], Proceedings of $4 \mathrm{~T}$ Turkish Design History Society Meetings "Kim(lik)lerin tasarımı" İzmir Ekonomi Üniversitesi, İzmir.

Kelley, T. (2001) The art of innovation. Harper Collins Business, London.

Kongar, E. (1997) 'Küresellesme ve kültürel farklılıklar çerçevesinde ulusal kültür'. [Globalization and national culture on cultural differences grounds]. Available: http://www. kongar.org/makaleler/mak_ku.php [26 Apr 2013].

Press. (2007) Available: http://www.nurus.com.tr/en/news/press/local/2007 [26 Apr 2013]. Porter, M. E. (1990) The competitive advantage of nations. Harvard Bussiness Review. 68(2). Available: http://kkozak.wz.cz/Porter.pdf [26 Apr 2013].

Said, E. (1985) Orientalism. London, Penguin Books.

Soykan, T. "'ilk in Milano' bir baslangic”. [ilk in Milano was a start]. (2007) [Photopraph of designs in 'ilk in Milano']. Natura. 116-117. Available: http://www.nurus.com.tr/files/images/ press/natura.jpg [26 Apr 2013].

'Tipsy Serving Tray'. [Photopraph of 'Tipsy Tray' a traditional tea serving tray by Koray Özgen]. Available: http://www.fitzsu.com/Ozgen-TIPSY-Serving-Tray.html [15 Feb 2014]. 'Türk tasarımcılardan Milano çıkarması'. [Milano invasion from Turkish designers]. (2007) Dünya. Retrieved from http://www.nurus.com/files/images/press/dunya.jpg [26 Apr 2013]. 